\title{
Influence of Rocks to The Hydrochemical Facies of Groundwater at Samigaluh Area, West Progo
}

\author{
T. Listyani R.A.

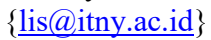 \\ Geological Engineering, ITNY
}

\begin{abstract}
Groundwater survey has carried out at Samigaluh and its surrounding area, West Progo. This area is included in West Progo Dome and topographic map of Sendangagung. This research has been done by hydrogeological survey, equipped with groundwater sampling of four samples for physical/chemical testing at laboratory. Field data collecting includes physical properties (color, taste, odor, turbidity) and chemical properties $(\mathrm{pH}$, TDS) of groundwater as well as local geological condition. Laboratory data is similar to field data plus ion contents. Data analysis includes hydrochemistry of groundwater based on all data. Results of research show that groundwater in research area is usually colorless, no taste, no odor and clear. Groundwater develops in most variable types, such as $\mathrm{Ca}-\mathrm{HCO}_{3}$, $\mathrm{Ca}, \mathrm{Na}-\mathrm{HCO}_{3}, \mathrm{Ca}, \mathrm{Na}, \mathrm{Mg}-\mathrm{HCO}_{3}$ and $\mathrm{Ca}, \mathrm{Mg}-\mathrm{SO}_{4}$. Groundwater types vary in some Piper class. The hydrochemical process is dominated by ion exchange, besides simple dissolution or mixing. The dominant groundwater facies are bicarbonate, due to the influence of siliciclastic rocks that interact with groundwater through the dissolution process. The number of elements $\mathrm{Ca}^{2+}, \mathrm{Na}^{+}$, and silica in the groundwater is influenced by the weathering of silicate minerals such as feldspar, plagioclase and clay minerals which derived from weathering minerals.
\end{abstract}

Keywords: hydrochemistry, groundwater, facies, process, rocks

\section{Introduction}

The research of groundwater was conducted in Samigaluh and its surrounding area, Kulon Progo District (Figure 1). The area is included in West Progo Dome physiographically [1], and the Indonesian Topographic Map Sheet 1408-232 (Sendangagung) [2] scale of 1:25.000. The research area is included in non-groundwater basin of West Progo Hills.

Hydrogeological research has been developed in various regions through some methods and goals in many regions in order to know about its quality and help society to get good quality of drinking water. The water is very important for human life, therefore water must be maintained as a valuable thing. Many kinds of research about groundwater need to be done to develop degree of life.

In recent days, groundwater is more important and replaces surface water for daily needs in some areas. The potential of groundwater in an area needs to be evaluated its properties in order to provide good quality of water. The properties usually include both physical and chemical ones, and sometimes they're completed with biological assessment. However, this research is focused on the physical and chemical properties of groundwater in study area. 


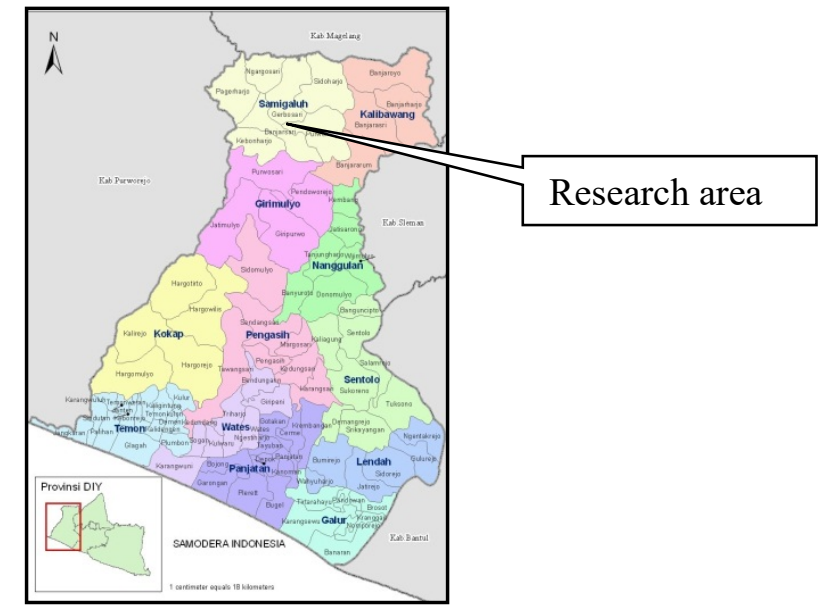

Fig. 1. Research area at Samigaluh and its surrounding region, West Progo District [3].

The potential of groundwater in certain areas is important to be determined from many aspects. This research has also been done to support groundwater potential understanding, especially on physical/chemical properties, and the influencing of rocks to groundwater. Hopefully, the result of the research can be united with other results of whole area, especially in West Progo Hills.

Potential groundwater in the research area has been studied using physical/chemical properties. By knowing these properties, the interpretation of groundwater quality and hydrochemical processes can be understood. The understanding of hydrochemical processes will help of understanding the geological condition in research area. Therefore, a good study of the hydrochemistry of a region is required. The various hydrochemical processes are controlled by the rocks of a region. Moreover, hydrogeological understanding can be approached by evaluating the diversity of the groundwater facies and its correlation with rocks in studied area.

\section{Methodology}

The research was primarily conducted by hydrogeological surveys in the field, especially for observing groundwater of dug wells and springs. There were 12 observation locations include four springs and eight dug wells. The tools used are standard geological tools (hammer, loupe, compass) and hydrogeology tools (pH-meter, TDS-meter, and sample bottles) as well as GPS equipment. Four groundwater samples were taken with polyethylene bottles, each of 1 liter of water. Then, groundwater samples tested their physical/chemical properties in the Chemical Laboratory of BBTKLP, Yogyakarta. The analysis was conducted on field data including petrology data of aquifer, geomorphology, and stratigraphy, and analysis of physical/chemical of groundwater in selected locations. Groundwater samples were taken at Ngaranduo well (W7) and Tulangan (S1), Jarakan (S5), Palem (S12) springs (Figure 2). Compilation of secondary data and primary data both of field a laboratory has been done to evaluate groundwater quality in research area. 


\section{Literature Review}

\subsection{Geological of Research Area}

The research area is physiographically included in West Progo Dome Zone (Fig. 2) [1]. This dome is part of the South Serayu Zone especially in the phenomena of the Dome Zone and the Hills in the Central Depression physiography. However, West Progo Dome has different orientations structurally with South Serayu Range.

Some geologists stated that the regional stratigraphy of West Progo Hill is composed of the oldest to the young by Nanggulan Formation, Old Andesite Formation, Jonggrangan Formation, Sentolo Formation and Alluvial Deposition. The Jonggrangan and Old Andesite Formations exposed in the research area.

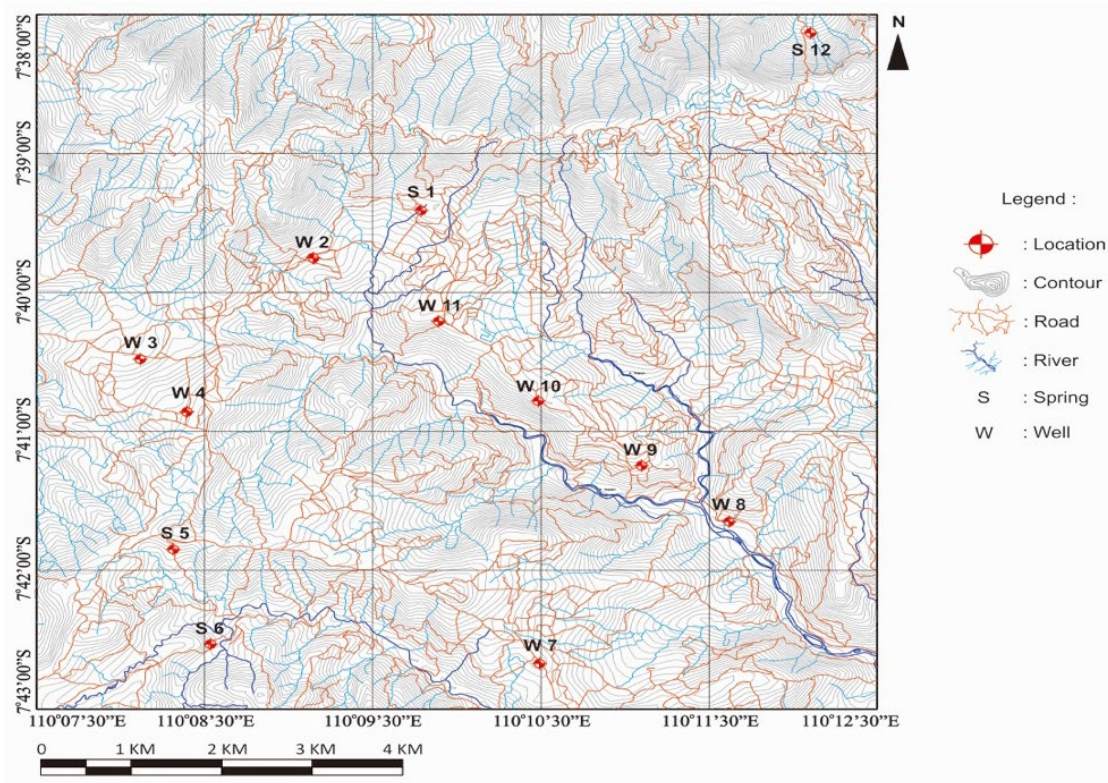

Fig. 2. Observation locations of research.

The Old Andesite Formation is exposed in most of the research area. It is deposited in a volcanic environment composed of volcanic breccia, lava, lapilli, lapilli tuff, and volcanic sandstone. The dominant lithology consists of andesite breccia with a tuff matrix, while fragments comprised of pyroxene to hornblende andesites. Besides this pyroclastic/epiclastic breccias, the intrusion of igneous rocks can be found locally.

The ancient volcanic activity located in West Progo Hills which produced Old Andesite Formation were Mt. Gadjah, Mt. Ijo and Mt. Menoreh. The Old Andesite Formation unconformably lay above Nanggulan Formation. The Old Andesite Formation can be separated based on the two depositional facies, namely Kaligesing and Dukuh Formation [4]. Kaligesing Formation is a land facies and consists of volcanic breccia, lava, and intercalation of tuff. The age of this formation is Late Oligocene to the Early Miocene, with a thickness of more than $600 \mathrm{~m}$. On the other hand, Dukuh Formation has deep-sea facies and composed of volcanic breccias as well as intercalation of sandstone, limestones, and claystone. This 
formation was deposited in Upper Oligocene to Early Miocene age, with thickness of more than $660 \mathrm{~m}$ and has interfingering relationship with Kaligesing Formation.

The lithology of West Progo Hills is dominated by volcanic materials such as andesite breccia, tuff, lapilli, agglomerate, and intercalation of andesite lava flows. The material is formed by the existence of ancient volcanic activity at Tertiary time. The lithology is usually impermeable and less porous. As a result, the water is difficult to be stored and flown in it. Therefore, the potential of groundwater in this region is very little. The presence of groundwater in this area is sometimes found in very deep layers ( $>25$ meters) and found only in rock fractures [5]. The need for the water for population at West Progo Hills is generally usually fulfilled by springs.

\subsection{Facies of Groundwater}

Groundwater quality is determined by its physical and chemical properties. This groundwater quality can be seen from its hydrochemical facies. Physical properties include color, taste, odor, temperature, and turbidity; while chemical properties depend on chemical composition of groundwater. The chemical composition of groundwater is influenced by minerals of rock. Each mineral has certain chemical composition which when dissolved will affect the chemical composition of groundwater.

The chemical facies of groundwater depends on the chemical composition of water in recharge area and reactions that occur in groundwater flow system [6]. In its flow process groundwater will pass many kinds of rocks beneath the surface of the earth. The rock will partially dissolved and influence the chemical content of groundwater. Mineral solubility in rocks depends on several things, such as pres.sure and temperature in groundwater basin and resistance of rocks.

Davis \& De Wiest (1966, in [7]) Groundwater quality is influenced by rock material in its path. Ion development in groundwater depends on mineral availability and mineral solubility. There is a relationship between groundwater compound ions in rock's mineral. Table 1 explains briefly about some chemical composition of groundwater and possibly source of minerals/rocks which influence it.

Groundwater compositions vary in their flow process. This chemical contents also change or experience evolution while groundwater flows under surface. From geochemical point of view, the order of anion evolution is greatly determined by mineral availability and solubility [9]. $\mathrm{HCO}_{3}{ }^{-}$ion content in groundwater commonly comes from $\mathrm{CO}_{2}$ of soil and calcite/dolomite dissolution. Because of big numbers of calcite and dolomite in almost all of sedimentary basin and these minerals are easily soluble, $\mathrm{HCO}_{3}{ }^{-}$almost be always dominant anion in recharge area.

Groundwater quality is influenced by aquifer materials caused by diagenetic changes when the groundwater passes the aquifer, caused by several hydrochemical processes [6]. These processes are dissolution-hydrolysis-precipitation, adsorption, ion exchange, reductionoxidation, mixing, membrane filtration, and microbiology metabolism.

One of the causes of mineralization in deep-lying water is long enough time of groundwater interaction to aquifer [6]. This fact will increase TDS from soluble salt or nonresistant minerals. Besides aquifer rock, claystone can also influence the chemical composition of groundwater by ion exchange processes. Clay can be a geochemical filter, natural chromatography or semipermeable membrane. 
Table 1. Mineral/rock association to chemical elements of groundwater (modified from Davis \& De Wiest, 1966 in [7] and [8]).

\begin{tabular}{|c|c|}
\hline $\begin{array}{l}\text { Element / } \\
\text { Compound }\end{array}$ & Minerals / Rocks \\
\hline $\mathbf{C a}^{2+}$ & $\begin{array}{l}\text { Marine sedimentary rocks (calcite, aragonite, dolomite, anhydrite, gypsum); a product of igneous } \\
\text { rock's weathering (feldspar, amphibole, pyroxene group, clay mineral). }\end{array}$ \\
\hline $\mathbf{N a}^{+}$ & Product of igneous rock's weathering, feldspar (albite), clay mineral. \\
\hline $\mathbf{K}^{+}$ & $\begin{array}{l}\text { Clay mineral, igneous rock's mineral (orthoclase, microcline, mica, biotite, feldspathoid, leucite, } \\
\text { nepheline). }\end{array}$ \\
\hline $\mathbf{M g}^{2+}$ & $\begin{array}{l}\text { It comes from soil and sediment, sedimentary rock (dolomite), igneous rock (biotite, hornblende, } \\
\text { augite. }\end{array}$ \\
\hline $\mathrm{NO}_{3}^{-}$ & $\begin{array}{l}\text { The atmosphere, the destructions of plants, animal breeds (organism activity), chemical source of } \\
\text { industry \& agriculture. }\end{array}$ \\
\hline $\mathrm{HCO}_{3}^{-}$ & $\begin{array}{l}\mathrm{CO}_{2} \text { from atmosphere and soil, soluble materials of calcareous rock (limestone \& dolomite), } \\
\text { precipitation of } \mathrm{CaCO}_{3}\end{array}$ \\
\hline $\mathrm{SO}_{4}{ }^{2-}$ & Oxidation of sulfide mineral in volcanic/igneous rock, atmospheric precipitation, organic shale \\
\hline $\mathrm{Cl}^{-}$ & Connate water trapped when sedimentation, the result of rain evaporation, atmospheric solubility. \\
\hline $\mathrm{SiO}_{2}$ & Feldspar, quartz, clay mineral, volcanic rock \\
\hline
\end{tabular}

As long as its flow under surface, groundwater tends to keep chemical equilibrium through chemical reactions to the environment. Equilibrium achieved tends to product stable groundwater quality to time cause of slow motion of groundwater and long residence time in geological formation [10]. Groundwater compositions vary in their flow process. The variable of groundwater quality commonly observed easier in shallow aquifer caused by seasonal variation at recharge and discharge area related to salinity fluctuation.

\section{Result and Analysis}

The geological setting of this region is composed of rock formations that are included in the West Progo Dome stratigraphy, such as Jonggrangan and Old Andesite Formation as well as the Quaternary sediments. The Old Andesite Formation that comprises the research area is generally included as Dukuh Formation, evenly spread in almost all parts of research area. Whereas, Jonggrangan Formation has outcrops locally spread or locally at narrow area.

The research area dominantly consists of andesite breccias. This rock can potentially act as aquifer through many cracks of joints (Figure 3). The andesite breccias show dark brown to black color when weathered and grey in fresh condition, with pyroclastic texture, and massive structure. The fragment of rock consists of andesite with feldspar, pyroxene, biotite dominantly and fewer quartz minerals. Whereas, the matrix usually is dark grey and consists of tuff.
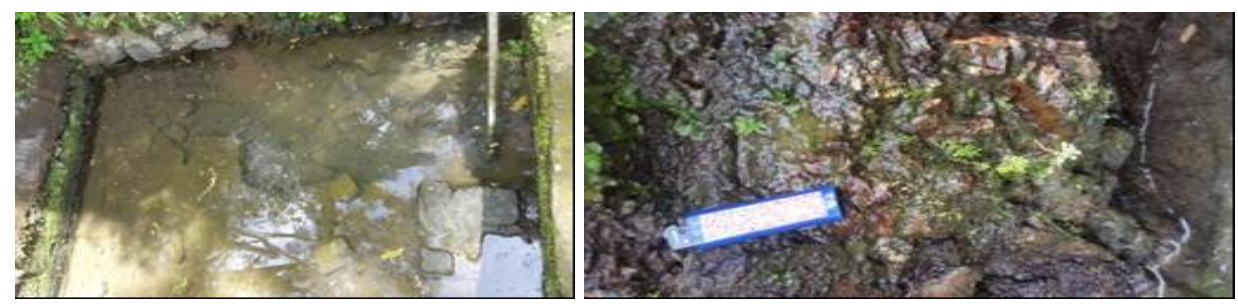

Figure 3. Left: Springs at Jarakan, Kebonharjo (Loc. 5). Right: Aquifer of andesite breccia in the spring. 
Field data has been taken directly from the area of dug wells and springs (Figure 2; Table 2). The physical/chemical properties of groundwater results from the laboratory are given in Table 3.

\subsection{Physical Properties of Groundwater}

Field data showed good quality of groundwater both in wells and springs. They showed colorless, no taste, no odor and clear of groundwater almost in all locations. Anomalous properties were only found at W7 and W9 that were slightly colored. The temperature of groundwater is usually normal, similar to the air temperature around wells and springs. Laboratory data also showed similar properties, where anomalous can be found at S12 with turbidity reached 5 NTU. Nevertheless, groundwater in research area is still a good physical property for daily needs.

Table 2. Field data of the physical/chemical properties of groundwater.

\begin{tabular}{cclrlrrr}
\hline Loc. & Type & \multicolumn{1}{c}{ Color } & Taste & Odor & Turbidity & pH & TDS \\
\hline S1 & Spring & Colorless & no taste & no odor & clear & 7 & 83 \\
W2 & Well & Colorless & no taste & no odor & clear & 6.9 & 45 \\
W3 & Well & Colorless & no taste & no odor & clear & 6.8 & 58 \\
W4 & Well & Colorless & no taste & no odor & clear & 7 & 29 \\
S5 & Spring & Colorless & no taste & no odor & clear & 7 & 33 \\
S6 & Spring & Colorless & no taste & no odor & clear & 6.8 & 30 \\
W7 & Well & Almost colorless & no taste & no odor & clear & 6.8 & 324 \\
W8 & Well & Colorless & no taste & no odor & clear & 6.8 & 68 \\
W9 & Well & Whitish & no taste & less odor & clear & 6.8 & 44 \\
W10 & Well & Colorless & no taste & no odor & clear & 6.8 & 61 \\
W11 & Well & Colorless & no taste & no odor & clear & 6.8 & 69 \\
S12 & Spring & Colorless & no taste & no odor & clear & 7 & 48 \\
\hline
\end{tabular}

Table 3. Laboratory testing of the physical/chemical properties of groundwater.

\begin{tabular}{lrrrr}
\hline \multicolumn{1}{c}{ Parameter } & \multicolumn{1}{c}{$\mathrm{S} 1$} & \multicolumn{1}{c}{ S5 } & \multicolumn{1}{c}{ W7 } & \multicolumn{1}{c}{$\mathrm{S} 12$} \\
\hline $\mathbf{C a}^{2+}(\mathbf{m g} / \mathbf{l})$ & 61.6 & 15.2 & 209.6 & 23.2 \\
$\mathbf{N a}^{+}(\mathbf{m g} / \mathbf{l})$ & 33 & 24 & 68 & 38 \\
$\mathbf{K}^{+}(\mathbf{m g} / \mathbf{l})$ & 3 & 1 & 8 & 4 \\
$\mathbf{M g}^{\mathbf{2 +}}(\mathbf{m g} / \mathbf{l})$ & 8.26 & 5.83 & 63.18 & 5.83 \\
$\mathbf{F e}^{2+}(\mathbf{m g} / \mathbf{l})$ & 0.0162 & 0.0541 & 0.0162 & 0.0221 \\
$\mathbf{M n}^{2+}(\mathbf{m g} / \mathbf{l})$ & 0.0101 & 0.0101 & 0.0101 & 0.0101 \\
$\mathbf{Z n}^{2+}(\mathbf{m g} / \mathbf{l})$ & 0.0083 & 0.0083 & 0.0083 & 0.0083 \\
$\mathbf{N O}_{3}^{-}(\mathbf{m g} / \mathbf{l})$ & 1.85 & 1.33 & 3.08 & 7.73 \\
$\mathbf{H C O}_{3}^{-}(\mathbf{m g} / \mathbf{l})$ & 252.4 & 90.6 & 300.5 & 114.2
\end{tabular}




\begin{tabular}{|c|c|c|c|c|}
\hline $\mathrm{SO}_{4}^{2-}(\mathrm{mg} / \mathrm{l})$ & 2 & 1 & 894 & 6 \\
\hline $\mathrm{Cl}^{-}(\mathrm{mg} / \mathrm{l})$ & 2.5 & 2 & 6.4 & 4.5 \\
\hline $\mathrm{SiO}_{2}$ & 17.691 & 15.543 & 11.823 & 17.212 \\
\hline pH & 6.1 & 5.7 & 6.8 & 6.1 \\
\hline Turbidity (NTU) & 1 & 2 & 1 & 5 \\
\hline Taste & no & no & no & no \\
\hline Odor & no & no & no & no \\
\hline Temperature $\left({ }^{\circ} \mathrm{C}\right)$ & 25.2 & 25.2 & 25.2 & 25.2 \\
\hline TDS (mg/l) & 178 & 85 & 1269 & 122 \\
\hline
\end{tabular}

\subsection{Chemical Properties of Groundwater}

Good properties of groundwater were also shown from chemical ones, such as normal $\mathrm{pH}(6.8$ - 7) at the field and $5.7-6.8$ from the laboratory. TDS commonly are low, except groundwater from W7 which reached $1269 \mathrm{ppm}$. Based on TDS value, groundwater of research area is freshwater according to Carroll, 1962 in [10].

Chemical contents of four samples show anion dominant as $\mathrm{HCO}_{3}{ }^{-}$, while cation dominant is usually varied. From laboratory data, samples from springs (S1, S5, S12) show $\mathrm{Ca}-\mathrm{HCO}_{3}, \mathrm{Ca}, \mathrm{Na}, \mathrm{Mg}-\mathrm{HCO}_{3}$ and $\mathrm{Ca}, \mathrm{Na}-\mathrm{HCO}_{3}$ facies subsequently, while sample from dug well at Ngaranduo (W7) show $\mathrm{Ca}, \mathrm{Mg}_{-} \mathrm{SO}_{4}$ facies (Table 4). The numbers of ion compositions of samples (in epm) can be seen at Stiff Diagram (Figure 5). It is clear that bicarbonate will be dominant facies of groundwater samples.

Table 4. Groundwater facies of samples of the research area.

\begin{tabular}{|c|c|c|c|c|c|}
\hline No. & Parameter & S1 & S5 & W7 & S12 \\
\hline \multicolumn{6}{|c|}{ Cation } \\
\hline 1 & $\mathrm{Ca}(\%)$ & 65.02 & 40.02 & 58.94 & 41.60 \\
\hline 2 & $\mathrm{Na}(\%)$ & 17.85 & 32.38 & 9.80 & 34.92 \\
\hline 3 & K (\%) & 2.76 & 2.29 & 1.96 & 6.25 \\
\hline 4 & $\operatorname{Mg}(\%)$ & 14.37 & 25.30 & 29.29 & 17.23 \\
\hline \multicolumn{6}{|c|}{ Anion } \\
\hline 5 & $\mathrm{Cl}(\%)$ & 1.66 & 3.61 & 0.76 & 5.98 \\
\hline 6 & $\mathrm{HCO}_{3}(\%)$ & 97.36 & 95.06 & 20.76 & 88.14 \\
\hline 7 & $\mathrm{SO}_{4}(\%)$ & 0.98 & 1.33 & 78.47 & 5.88 \\
\hline \multicolumn{2}{|c|}{ Chemical type } & $\begin{array}{c}\mathrm{Ca}- \\
\text { bicarbonate }\end{array}$ & $\begin{array}{l}\mathrm{Ca}, \mathrm{Na}, \mathrm{Mg}- \\
\text { bicarbonate }\end{array}$ & $\begin{array}{l}\mathrm{Ca}, \mathrm{Mg}- \\
\text { sulfate }\end{array}$ & $\begin{array}{c}\mathrm{Ca}, \mathrm{Na} \text { - } \\
\text { bicarbonate }\end{array}$ \\
\hline
\end{tabular}

Bicarbonate facies is the dominant groundwater type in the research area. The anomalous which is found in well number W7 as sulfate facies may be caused by pollution of groundwater. The pollution possibly came from human activity such as household waste, industry or agriculture, in addition to the possibility of organic shale in the place. 


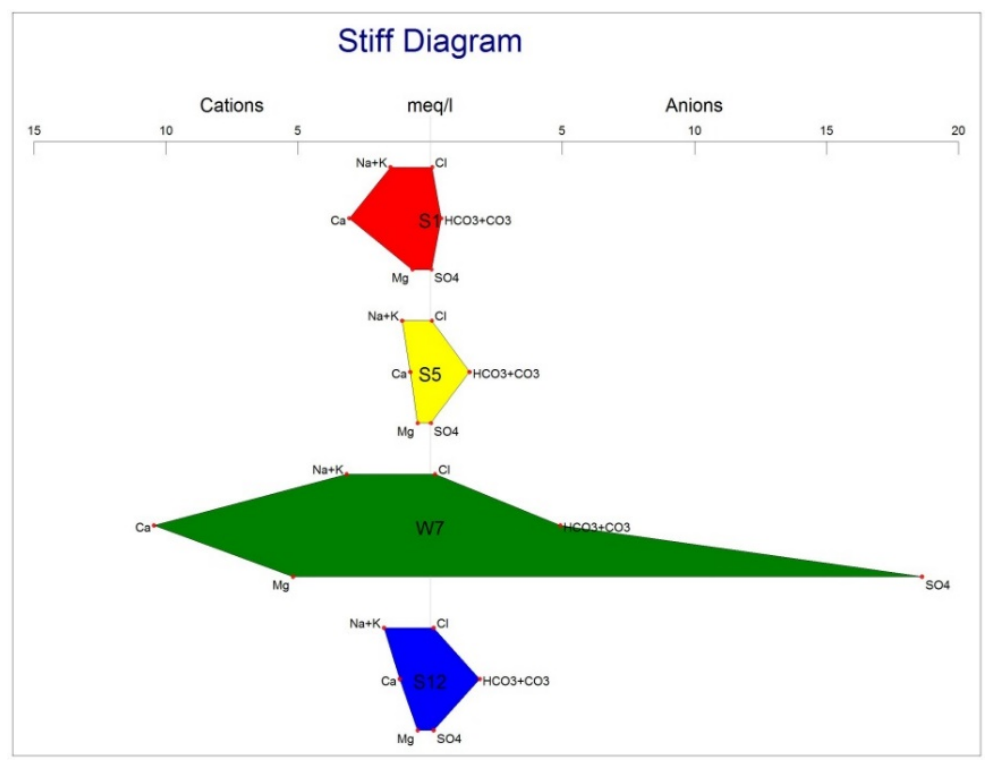

Fig. 5. Stiff diagram of groundwater samples.

The plot of groundwater samples in Piper diagram (Figure 6) shows that groundwater in research area has several varied types. Those samples include in many classes of Piper division, i.e. class $1-6$ and class 9 .

Groundwater from S1, S5 and W7 are included in class 1, indicate that earth alkaline content more than alkaline. Groundwater from S12 is included in class 2 which means it has alkaline content more than earth alkaline. Class 3 consists of S1, S5, and S12 which means that weak acid content more than strong acid. Class 4 involves groundwater from W7 which means strong acid more than weak acid contents. Class 5 shows that calcareous hardness or secondary alkalinity more than $50 \%$, for example groundwater of S1 and S5. Class 6 shows that non calcareous hardness or secondary salt consists of groundwater from W7 sample. Whereas, class 9 show cation-anion equilibrium in groundwater like in S12 sample.

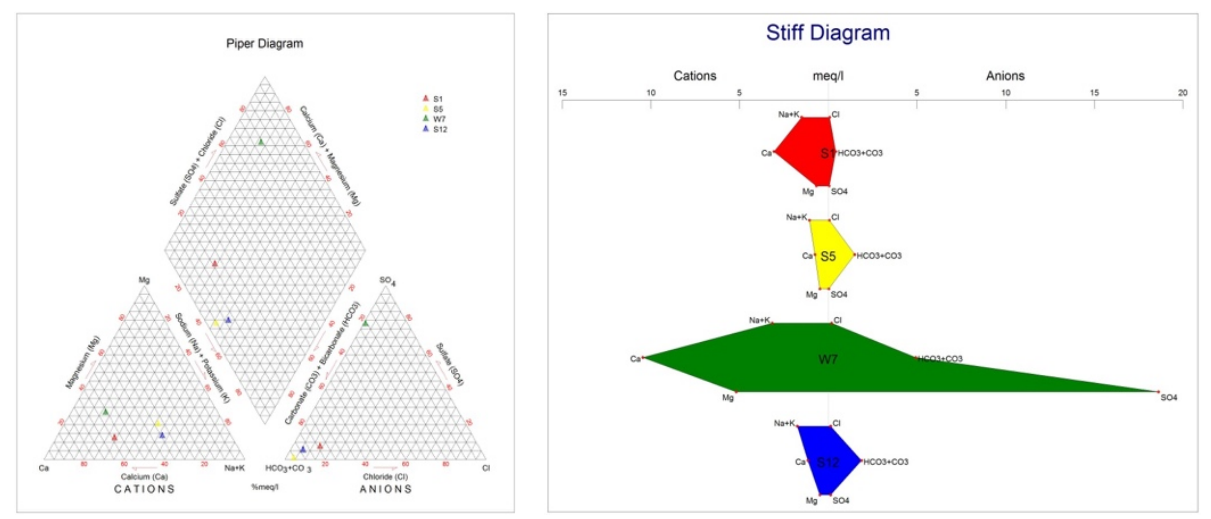




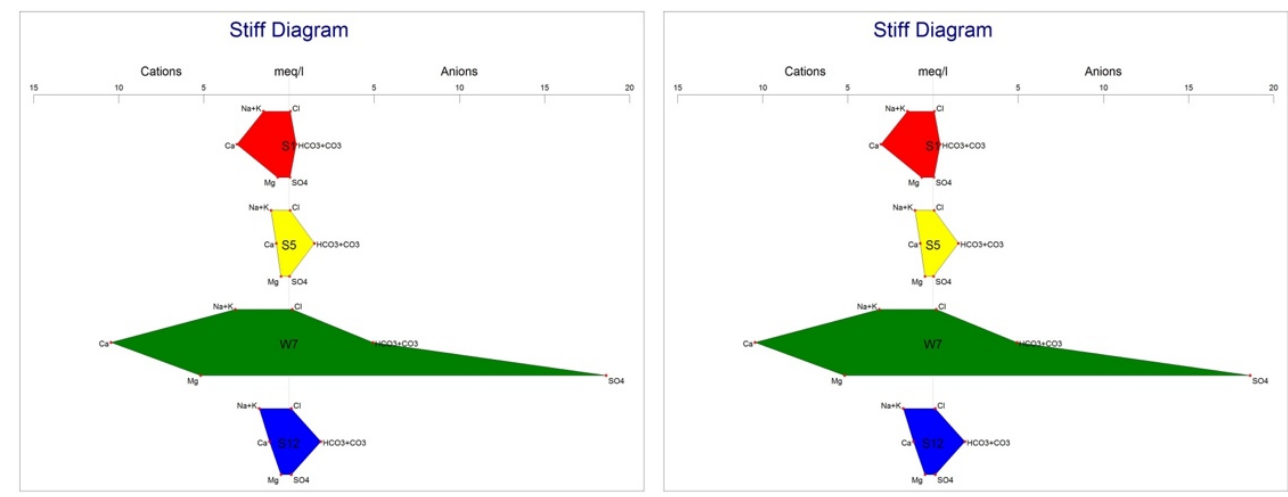

Fig. 6. A plot of groundwater samples in Piper diagram.

The hydrochemical process along the groundwater flow path was dominated by ion exchange, especially as shown by S12, S5 and S1 samples (Figure 7). Although the process in $\mathrm{S} 1$ is more advanced, this does not mean that groundwater flows from S12 to S5 and S1. It can be understood because groundwater flows locally. Whereas, the W7 sample tends to show the other dominant process i.e. simple dissolution or mixing. It may be due to pollution in the dug well area from the environment. It also supported high enough of TDS in groundwater of W7 sample according to laboratory tests that show brackish water type (Carroll, 1962 in [10]).

The hydrochemical process as indicated in Figure 8 does not clearly describe the order of the groundwater journey. The pattern of groundwater flow in the research area is still not understanding comprehensively since the area is a non-groundwater basin area. This means that groundwater flow patterns are often local, and may not be interconnected in the basin.

Groundwater in research area flows mostly in volcanic rocks with igneous rock fragments. The igneous rock origin generally contains appreciable amounts of aluminosilicate minerals such as feldspar and mica [11]. Groundwater would be acquired dissolved constituents from the dissolution process. However, silica contents $\left(\mathrm{SiO}_{2}\right)$ of groundwater in research were still low $(<18 \mathrm{ppm})$. It means that dissolution process (even in W7) has not gone perfectly or the process takes place in a relatively short time. It indicates that groundwater flow is local or near journey. This characteristic is usually possessed by young groundwater in recharge area.

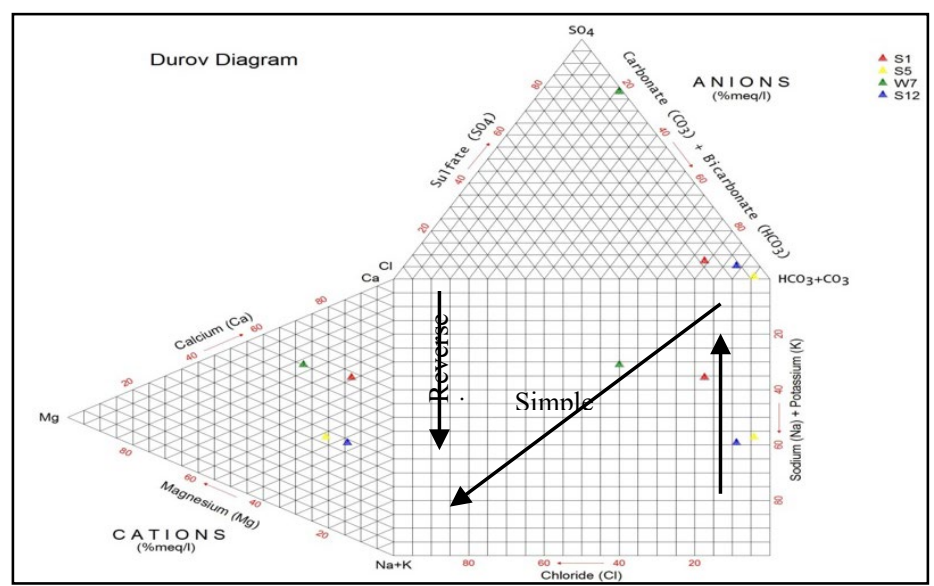

Fig. 7. A plot of groundwater samples in Durov diagram 


\subsection{Rock's Mineral Composition}

Rocks affect the chemical characteristics of groundwater through the process of dissolving the minerals they contain [12], [13]. Therefore, the study of the influence of rocks on groundwater hydrochemical is carried out by analyzing the mineral content of rock constituents. Table 5 below shows the composition of rock minerals in the study area. The rocks that make up the Samigaluh area are dominated by pyroclastic andesite breccia and andesite igneous rocks. The rock has the main mineral feldspar (plagioclase) and volcanic glass [14]. One example of mineral appearance in a thin section of rock is shown in Figure 8.

\subsection{Influence of Rock's Mineral to Groundwater Facies}

The research area dominantly consists of volcanic rocks, especially of andesite breccia. These rocks are included in Old Andesite Formation which may become aquifer by their cracks or weathering products. The groundwater which flows in this formation may be influenced by elements of rock's minerals. The interaction of water - tuffaceous rocks on the main aquifer is the reaction of dissolution - precipitation because these rocks indicate chemically unstable phase [15]. Carbonate aquifer is also found in Samigaluh although its spread is narrow. This carbonate aquifer also has unstable chemical phase, so the reaction of dissolution is occurring easily.

Table 5. Mineral composition in rocks in the study area (\%) [14].

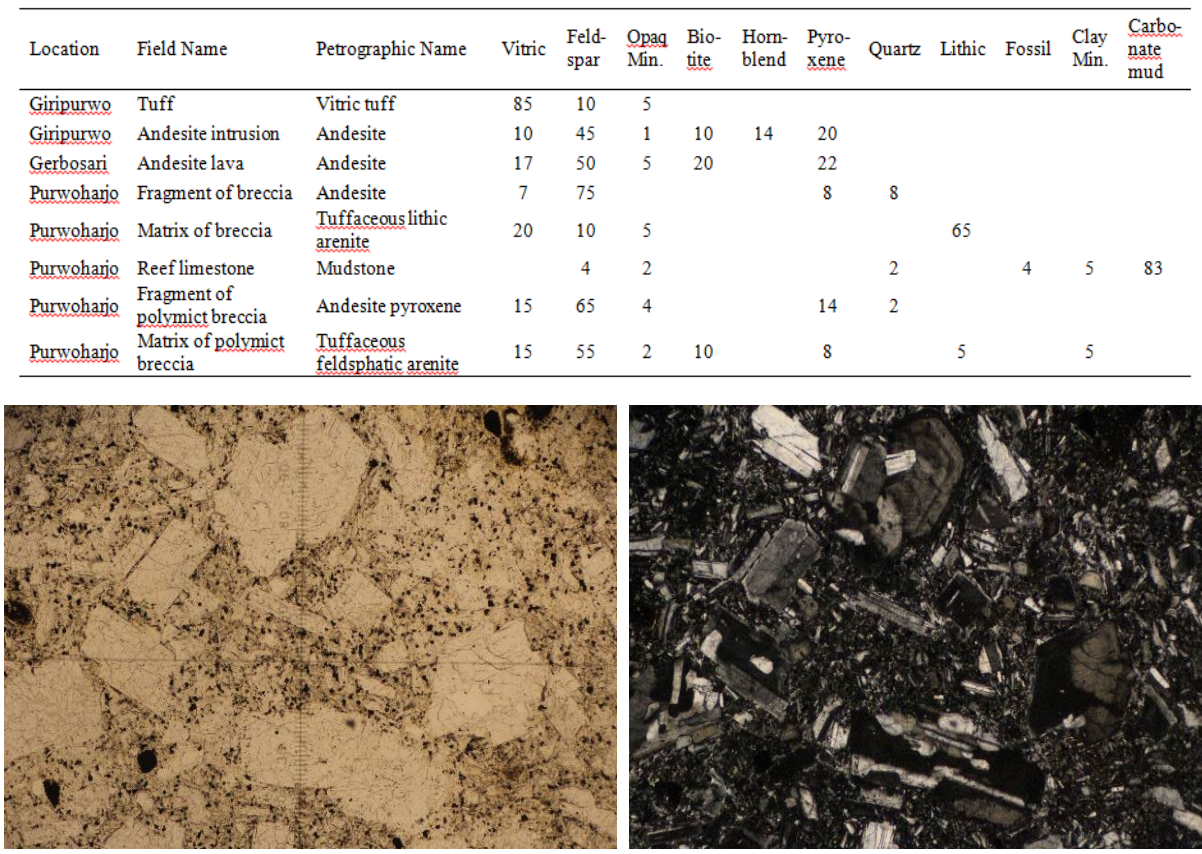

Figure 8. Examples of andesite thin cuts from the study area in parallel nicol (left) and cross nicol (right) [14]. 
The dominant groundwater facies are bicarbonate, with sulfate facies anomalies. Sulfates can originate from oxidation of sulfide minerals in igneous/volcanic rocks or atmospheric precipitation [8]. Significant sulfate content can also be caused by pollution factors.

Petrographic data shows the presence of rocks containing clay minerals. This might occur due to weathering in rocks. This clay mineral usually has ion exchange capacity which influences the type and quality of groundwater.

However, the main mineral that consists of rocks in the study area is plagioclase. This silicate mineral is easily weathered (Goldich, 1938, in [16]) so that the dissolution of the rock is very influential in the high silica content in the groundwater.

Minerals content in the siliciclastic tuffaceous and calcareous rocks in a research area, together influence the chemical content of groundwater. These minerals supply chemical elements such as $\mathrm{Ca}^{2+}, \mathrm{Mg}^{2+}, \mathrm{Na}^{+}, \mathrm{Cl}^{-}$, carbonates, and bicarbonates (Table 6). This table shows that the mineral constituent of rocks in the study area may play a role in affecting the composition of groundwater. The table shows the possibilities of supply of chemical elements from the existing mineralogy. Furthermore, the elements / compounds present in groundwater is affected by the level of mineral solubility. Not all minerals can dissolve the elements contained in them.

Table 6. Correlation of petrographic data and groundwater chemistry association with chemical groundwater data.

\begin{tabular}{|c|c|c|c|}
\hline \multirow{2}{*}{ Mineral } & \multirow{2}{*}{$\begin{array}{l}\text { Chemical association in rocks } \\
\text { (Davis \& De Wiest, } 1966 \text { in [13]) }\end{array}$} & \multicolumn{2}{|c|}{$\begin{array}{l}\text { Chemical facies of } \\
\text { groundwater }\end{array}$} \\
\hline & & $\begin{array}{l}\text { Dominant } \\
\text { Cation }\end{array}$ & $\begin{array}{l}\text { Dominant } \\
\text { Anion }\end{array}$ \\
\hline Feldspar & Silica, $\mathrm{Ca}^{2+}, \mathrm{Mg}^{2+}, \mathrm{Na}^{+}, \mathrm{K}^{+}$ & \multirow{9}{*}{$\begin{array}{l}\mathrm{Ca}^{2+} \\
\mathrm{Mg}^{2+} \\
\mathrm{Na}^{+}\end{array}$} & \multirow{9}{*}{$\begin{array}{l}\mathrm{HCO}_{3-}^{-} \\
\mathrm{SO}_{4}^{2-}\end{array}$} \\
\hline Clay mineral & Silica, $\mathrm{Fe}^{2+}, \mathrm{Fe}^{3+}, \mathrm{Ca}^{2+}, \mathrm{Mg}^{2+}, \mathrm{Na}^{+}, \mathrm{K}^{+}, \mathrm{SO}_{4}{ }^{2-}$ & & \\
\hline Opaque mineral & Silica, $\mathrm{Fe}^{2+}, \mathrm{Fe}^{3+}, \mathrm{Mg}^{2+}$ & & \\
\hline Volcanic glass & Silica, $\mathrm{SO}_{4}{ }^{2-}, \mathrm{Cl}^{-}$ & & \\
\hline Rock fragment & Silica, $\mathrm{Fe}^{2+}, \mathrm{Fe}^{3+}, \mathrm{Ca}^{2+}, \mathrm{Mg}^{2+}, \mathrm{Na}^{+}, \mathrm{K}^{+}, \mathrm{SO}_{4}^{2-}, \mathrm{Cl}^{-}$ & & \\
\hline Quartz & Silica & & \\
\hline Pyroxene & $\mathrm{Fe}^{2+}, \mathrm{Fe}^{3+}, \mathrm{Ca}^{2+}$ & & \\
\hline $\begin{array}{l}\text { Fossil \& carbonate } \\
\text { mineral }\end{array}$ & $\mathrm{Ca}^{2+}$, carbonate, bicarbonate & & \\
\hline Hornblende & $\mathrm{Fe}^{2+}, \mathrm{Fe}^{3+}, \mathrm{Ca}^{2+}, \mathrm{Mg}^{2+}, \mathrm{Cl}^{-}, \mathrm{F}$ & & \\
\hline
\end{tabular}

Silica content in the groundwater supply is obtained from several minerals include feldspar, clay minerals, opaque minerals, volcanic glass, quartz and rock fragments (lithic). The process of the dissolution of this mineral can be supported by the weathering of silicate minerals, which can be explained as follows [16].

- Changes resulting in the chemistry of groundwater is unclear because of the dissolution of weathered silicate minerals generally run very slowly. This is evident from all samples of groundwater that show the small amount of content of silicate. 
- In many siliciclastic rocks area, effect of silicate weathering on groundwater chemistry is usually mainly the addition of cations and silica.

- The disappearance sequence of silicate minerals indicates differences in the dissolution rate. In accordance with the Goldich sequence of weathering (1938, in [16]), feldspar is more easily weathered than quartz, then feldspar mineral is more possibly supply of silica in groundwater than quartz.

The chemical content in groundwater is strongly influenced by mineral solubility [10]. This is, of course, depends on their mineral stability. The dominant soluble minerals in the area are feldspar and carbonate minerals. The other silicate minerals can support the chemical content of groundwater due to leaching that occurs in quite a long time. Thus, the characteristics of the groundwater facies are heavily influenced by rock.

Volcanic rocks at the Samigaluh area are pyroclastic or volcaniclastic rocks. Leaching in these volcanic sedimentary rocks (especially from its matrix) will affect the composition of the groundwater for their soluble component [17]. TDS depends on the material of rocks. Low TDS in groundwater can be caused by rainwater. The arenite sandstone may result many elements of $\mathrm{Mg}^{2+}, \mathrm{Ca}^{2+}, \mathrm{Na}^{+}, \mathrm{SO}_{4}^{2-}$ dan $\mathrm{Cl}^{-}$in groundwater.

The effect of rocks on hydrochemical facies is also supported by a method that connects ionic concentrations with TDS. Figure 9 shows a plot of groundwater chemical data that falls on rock dominance and mineralization fields [18]. This reinforces the prediction of the influence of rocks on the hydrochemical facies and the effect of mineralization due to groundrock ground interaction.

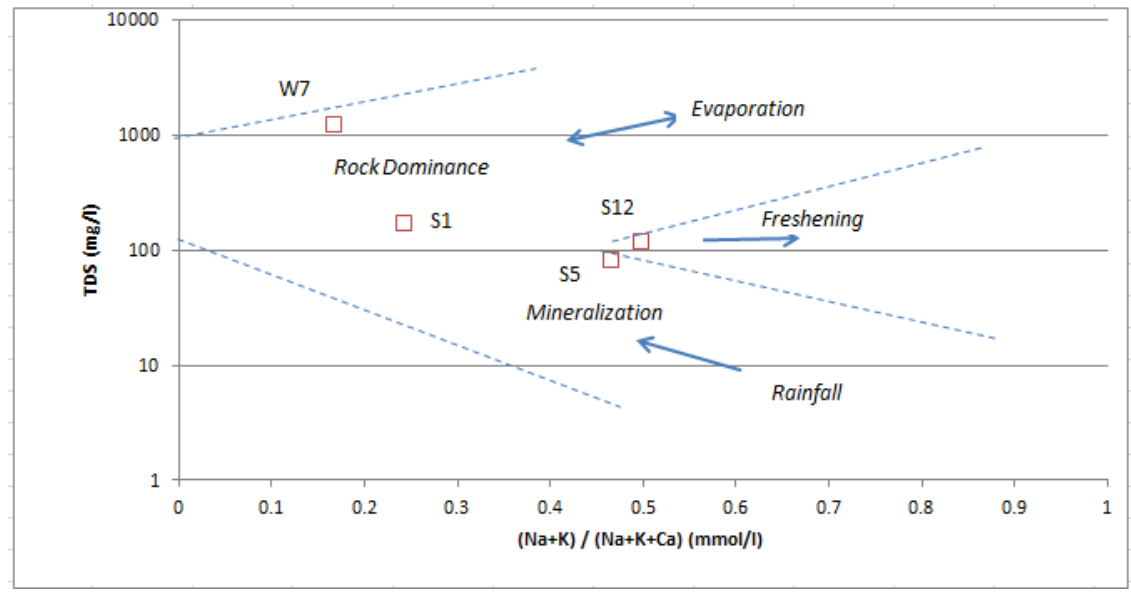

Figure 9. Plot data in Gibb's diagram show rock dominance and mineralization as a major process of hydrochemical in research area.

\section{Conclusion}

Groundwater in the research area is dominated by bicarbonate types, although there was anomalous of sulfate type can be found at well in Ngaranduo. The hydrochemical types develop as $\mathrm{Ca}-\mathrm{HCO}_{3}, \mathrm{Ca}, \mathrm{Na}, \mathrm{Mg}-\mathrm{HCO}_{3}$ and $\mathrm{Ca}, \mathrm{Na}-\mathrm{HCO}_{3}$, and $\mathrm{Ca}, \mathrm{Mg}-\mathrm{SO}_{4}$. The other characteristics show neutral $\mathrm{pH}(5,7-7)$ and low TDS (freshwater) although in laboratory it was found brackish water at Ngaranduo well. The dominant hydrochemical process is ion exchange, in addition to simple dissolution or mixing that may become from any pollution. 
The study area dominantly consists of volcaniclastic rocks. Some of the mineral content of the rocks are soluble easily in groundwater as a result of the weathering process. The content of cations and anions in the groundwater is affected by the composition of the minerals that compose the rock. The number of elements $\mathrm{Ca}^{2+}, \mathrm{Na}^{+}$, and silica in the groundwater is affected by the weathering of silicate minerals such as feldspar, plagioclase and clay minerals which derived from weathering minerals.

\section{References}

[1] Van Bemmelen R W 1949 The Geology of Indonesia Vol. 1A (Netherland: Martinus Nijhoff The Hague).

[2] Bakosurtanal 2000 Indonesian Topographic Map of Sendangagung Sheet Number 1408-232, $1^{\text {st }}$ Ed. (Cibinong: Bakosurtanal).

[3] Anonim 2013 Kulon Progo http://bamportal.blogspot.co.id.

[4] Pringgoprawiro H \& Riyanto B 1987 Old Andesite Formation - A Revision Proc. IAGI XVI Bandung.

[5] Anonim 2014 General Review of West Progo District http://www. ppsp.nawasis.info.

[6] Matthess G 1982 The Properties of Groundwater (New York: John Wiley \& Sons, Inc.).

[7] Listyani R A T 2016 Hydrochemistry of Groundwater in Geyer, Grobogan Province, Central Java, Journal Technology of Civil, Electrical, Mechanical, Geology, Mining, and Urban Design KURVATEK, Vol 1, No. 2 (Yogyakarta: STTNAS)

https://journal.sttnas.ac.id/krvtk/article/view/230/pdf 1

[8] Bowen R 1986 Groundwater $2^{\text {nd }}$ Ed. (London: Applied Science Publisher) 227 p.

[9] Freeze R A and Cherry J A 1979 Groundwater (New Jersey: Prentice-Hall, Inc., Englewood Cliffs).

[10] Todd D K 1980 Groundwater Hydrology $2^{\text {nd }}$ Ed. (New York: John Willey \& Sons Inc.).

[11] Domenico P A and Schwartz F W 1990 Physical and Chemical Hydrogeology (New York: John Wiley \& Son).

[12] Listyani R A T 2016 Hydrochemistry of Groundwater in Yogyakarta Graben, Area of Code Sub Drainage, Yogyakarta, Indonesia, $5^{\text {th }}$ Annual International Conference on Geological \& Earth Sciences (GEOS 2016) (Singapore: GSTF). www.tomorrowpeople.org; https://www.researchgate.net/publication/325192817 RDC 2017 My Conference pro $\underline{\text { ceedings }}$

[13] Listyani R A T 2016 Rock's Mineral Control on Groundwater Quality in Jakarta Groundwater Basin, Proceedings of $11^{\text {th }}$ Nasional Rekayasa Teknologi Industri dan Informasi (ReTII) Seminar (Yogyakarta: STTNAS) ISSN 1907-5995, 10 December 2016.

https://journal.sttnas.ac.id/ReTII/article/view/500/425

[14] Abdillah F 2017 Geology and Vulnerability Analysis of Soil Movement with the Storie Method of Purwoharjo Area and Surrounding, Samigaluh District, Kulon Progo Regency, Special Region of Yogyakarta, Undergraduate Thesis (Yogyakarta: STTNAS).

[15] Fisher R S \& Mullican W F 1997 Hydrochemical Evolution of Sodium Sulfate and Sodium Chloride Groundwater beneath The Northern Chihuahuan Desert, Trans-Pecos, Texas, USA. Hydrogeology Journal Vol. 5 No. 2 (Germany: Verlag Heinz Heise $\mathrm{GmbH} \& \mathrm{Co} \mathrm{KG})$. 
[16] Appelo C A J \& Postma D 1996 Geochemistry, Groundwater \& Pollution (Netherland: A.A. Balkema).

[17] Matthess G 1982 The Properties of Groundwater (New York: John Wiley \& Sons, Inc.).

[18] Gibbs R J 1970 Mechanism Controlling World Water Chemistry Science New Series, Vol 170 No. 3962 Dec 4, 1970, pp. 1088 - 1090 American Association for the Advancement of Science. http://www.jstor.org/stable/1730827 